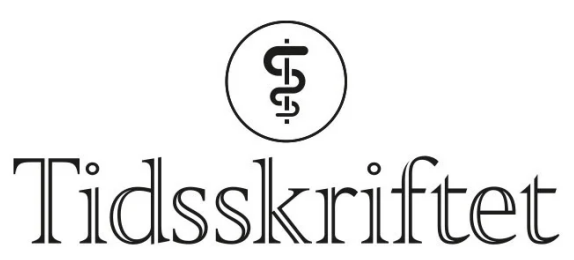

DEN NORSKE LEGEFORENING

\title{
Foretaksmodellen må skrotes
}

\author{
DEBATT
}

TORGEIR BRUUN WYLLER

Department of Geriatric Medicine

Oslo University Hospital

and

Institute of Clinical Medicine

University of Oslo

He has contributed to the idea, design, data interpretation, literature search, drafting and revision of the manuscript and approval of the submitted manuscript version.

Torgeir Bruun Wyller, specialist in internal medicine and geriatric medicine, senior consultant and professor.

The author has completed the ICMJE form and declares no conflicts of interest.

\section{Foretaksmodellen innebærer at sykehusene driftes etter kvasikapitalistiske prinsipper. Det fører til at de prioriterer bedrifts $\varnothing$ konomisk «lønnsomhet» foran helsefaglig og samfunnsøkonomisk ansvarlighet.}

Innføringen av helseforetakene i 2002 hadde to elementer. For det første at staten overtok eierskapet for sykehusene, og for det andre at driften ble basert på prinsipper som best kan beskrives som markedsimitasjon eller kvasikapitalisme. Kritikk blir ofte møtt med at «ingen» vil tilbake til fylkeskommunene som sykehuseiere. Men det er mulig å beholde statlig eierskap uten at sykehusene trenger å være kvasikapitalistiske foretak.

Foretaksorganiseringen av sykehusene bør avvikles fordi foretakene har markedsimitasjon som sitt bærende prinsipp. Man rigger seg til som om sykehusene var konkurrenter, noe de nettopp ikke er i Norge. Driftsmodeller som har vist seg egnet til å styre profittdrevne konsern som skal konkurrere i et marked, gir ikke en hensiktsmessig styring av velferdstjenester som ytes på fellesskapets vegne og ikke har profitt som motiv. Det er tre grunner til det:

For det første fører markedsimitasjonen til at omsorg for egen budsjettbalanse prioriteres foran samarbeid om god behandling og samfunnsøkonomisk forsvarlighet. Det som er viktig for samfunnet, er ikke at foretak A pynter på sitt driftsregnskap ved å skyve utgifter over på foretak B eller kommune C. Det viktige er at fellesskapets ressurser samlet sett brukes på best mulig måte for å gi borgerne gode tjenester. Da er markedsimitasjon et uegnet virkemiddel. 
For det andre fører markedsimitasjon til vekst i administrasjon, kontroll og annet uproduktivt arbeid for å unngå at sykehusene blir for ivrige i sine bestrebelser på å pynte på det bokførte regnskapet (1). Bedrifter som reduserer kostnadene for mye på kort sikt, vil over tid levere dårligere kvalitet. I et «ideelt marked» oppdager kundene det og velger et konkurrerende produkt. Men sykehusene opererer ikke i et slikt marked. Da må det mer kontroll til for å passe på at de ikke tar snarveier (f.eks. «kreativ» diagnosekoding) for å maksimere regnskapsførte inntekter.

For det tredje fører markedsimitasjon til et dårlig ytringsklima. Den gjør nemlig at sykehuset må pleie sitt omdømme. Det må se ut som sykehuset leverer god kvalitet, uansett om det er tilfellet. Kritiske innspill fra kompetente ansatte gir risiko for redusert omdømme, og blir dermed en trussel. For virksomheter der reell kvalitet og ikke omdømme teller, blir indre kritikk og meningsbryting derimot en kilde til kvalitetsforbedring.

Det kan med rette hevdes at det ikke bare er i foretaksorganiserte virksomheter vi ser en uhensiktsmessig markedsimitasjon. Liknende problemer oppleves i skolene, universitetene, NAV, Forsvaret og politiet, og ingen av disse er foretaksorganisert. Fjerning av helseforetakene er derfor ingen garanti for at den ressursødende markedsimitasjonen $\mathrm{i}$ sykehusene vil bli avskaffet. Likevel har helseforetakene i større grad enn andre offentlige

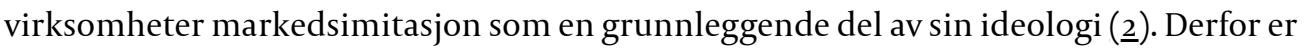
fjerning av foretaksmodellen en nødvendig, men ikke tilstrekkelig, forutsetning for å få slutt på en kvasikapitalisme som har vist seg kostnadsdrivende og som truer kvaliteten.

\section{Et bedre alternativ}

Det har tidligere vært et problem at kritikere av foretaksorganiseringen ikke har hatt noe konkret alternativ. Det er heldigvis nå endret. En gruppe fagfolk fra økonomi, statsvitenskap, medisin m.m. har på eget initiativ utredet og inngående beskrevet en alternativ organisering for sykehusene. Ikke alt er spikret, og modellen kan gjerne være gjenstand for debatt. Nettopp gjennom konstruktiv debatt kan alternativet finslipes og bli mest mulig troverdig. For detaljert beskrivelse av vårt alternativ, viser vi til originalpublikasjonen (3). Her gis kun noen stikkord:

Det enkelte sykehus er en selvstendig enhet med egen ledelse. Sykehusene eies av staten og er direkte finansiert, men med koordinerende regionale ledd som enten er direkte underlagt staten eller valgt regionalt. Regnskapsmodellen med krav til overskudd er forkastet, og sykehusene er underlagt ordinært forvaltningsregnskap, med rammefinansiering som hovedprinsipp. Stortinget vedtar årlig en rullerende nasjonal sykehus- og helseplan med investeringsprogram samt vedtar årlige rammer for driftsbudsjett og mindre investeringer til det enkelte sykehus. Det er et klart skille mellom midler til investeringer og driftsmidler.

\section{«Det viktige er at fellesskapets ressurser samlet sett brukes på best mulig måte for å gi borgerne gode tjenester. Da er markedsimitasjon et uegnet virkemiddel»}

Helseforetakene ble innført av Arbeiderpartiet og videreført av Høyre. Det er en utfordring at ingen av disse to partiene viser særlig vilje til å endre modellen. Uansett regjeringskonstellasjon etter valget, kan derfor minst ett dominerende regjeringsparti 
være uvillig til å gjøre de grunnleggende endringer som trengs. Den helsepolitiske debatten frem mot valget, og de forventede regjeringsforhandlingene etterpå, blir avgjørende for om det blir et politisk klima for å gjøre høyst påkrevde endringer i dagens modell.

\section{LITTERATUR}

1. Wyller TB. Profesjonalisme eller managerialisme? Intervju med Soki Choi. I: Haukelien H, Wyller TB. Ny helsepolitikk. Det finnes løsninger. Oslo: Dreyer, 2017: 125-32.

2. Slagstad R. Den nye helseadelen. Tidsskr Nor Legeforen 2017; 137. doi:10.4045/tidsskr.17.0400. [PubMed][CrossRef]

3. Haug L, Jensen B, Gisvold SE et al. Presentasjon av et alternativ til helseforetaksmodellen. Samfunn og økonomi. https://www.samfunnogokonomi.no/2021/o7/presentasjon-av-et-alternativ-tilhelseforetaksmodellen/ Lest 6.8.2021.

Publisert: 1. september 2021. Tidsskr Nor Legeforen. DOI: 10.4045/tidsskr.21.0573

(C) Tidsskrift for Den norske legeforening 2023. Lastet ned fra tidsskriftet.no 26. april 2023. 